Physical Geography; Cartography; Geographic Information Systems \& Spatial Planing

\title{
ASSESSMENT OF WATER QUALITY AND WATER POLLUTION OF THE LUDA MARA RIVER IN THE REPUBLIC OF MACEDONIA
}

DOI: http://dx.doi.org/10.18509/GBP.2015.03

UDC: 556.531:[502.51.504.5(97.714)

\author{
Dr. Kole Pavlov ${ }^{1}$ \\ Prof. D-r Gjorgi Pavlovski² \\ ${ }^{1}$ Josip Broz Tito High School, Skopje, Republic of Macedonia \\ ${ }^{2}$ Faculty of Pedagogy, Štip, Republic of Macedonia
}

\begin{abstract}
The Luda Mara River is a tributary of the Vardar River. Its total length stretches on 38.9 $\mathrm{km}$. The drainage area of the Luda Mara covers $140.5 \mathrm{~km}^{2}$ in the central parts of the country. In total 32,677 people inhabit eight settlements. The population in the catchment area of the Luda Mara River face several water management problems on a permanent basis, including: water supply of the population, agriculture and industry, as well as excessive erosion. The usage of the Luda Mara water for irrigation, but also for disposal of wastewater from households and industry, requires serious and constant monitoring of water quality. Therefore, the main purpose of the paper is aimed at systematic and meaningful assessment of quality and water pollution of the Luda Mara River based on some chemical indicators, particularly on heavy metals during 2010. Analysis of samples from water and sediment samples at three locations indicated that the lowest water quality of the Luda Mara River is downstream from the urban centre of Kavadarci. It reflects the anthropogenic pressure on the water flow, whether the upper section of the river shows better summative water quality. The lowest quality class is shown in terms of several parameters as: ammonia, cadmium, manganese and copper. Besides the assessment of water quality of the Luda Mara River, special emphasis was put on the identification of sources of natural and anthropogenic water pollution.
\end{abstract}

Keywords: The Luda Mara River, pollution/contamination, heavy metals, water quality.

\section{INTRODUCTION}

An initiative for quality assessment of the Luda Mara water was launched for several reasons. The drainage basin of this river has not been included in the national River Monitoring System (RIMSYS) of the Republic of Macedonia for the monitoring of the river water quality. The Luda Mara River drains wastewater from the Kavadarci urban settlement with its industrial facilities as well as wastewater from rural settlements in the drainage basin. At the same time, the watercourse features low level of flow and emphasised torrential character of the water regime, which has a high potential for environmental pollution in its own right [5]. Such a confirmed sign was also provided by undeniable organoleptic contamination of the watercourse resulting from visible hard waste and the smell of rot, as indication of prevalent organic decay in water, which the local population at the section downstream from Kavadarci, between the villages of Glisic and Marena, constantly feels (Fig. 2). Ultimately modest available water resources in the 
drainage basin, accompanied with numerous water supply problems, unavoidably leave traces in quality of water in general [6]. The subject of research in this paper was water of the Luda Mara River, or its condition according to the basic chemical parameters, in particular its load of some heavy metals as a criterion for quality. The goal of the study is to detect systemically the current quality, contamination and spatial distribution of heavy metals in the watercourse, as well as to identify natural and anthropogenic sources of contamination. The primary impulse towards the implementation of such an objective was the fact that in this respect, no special

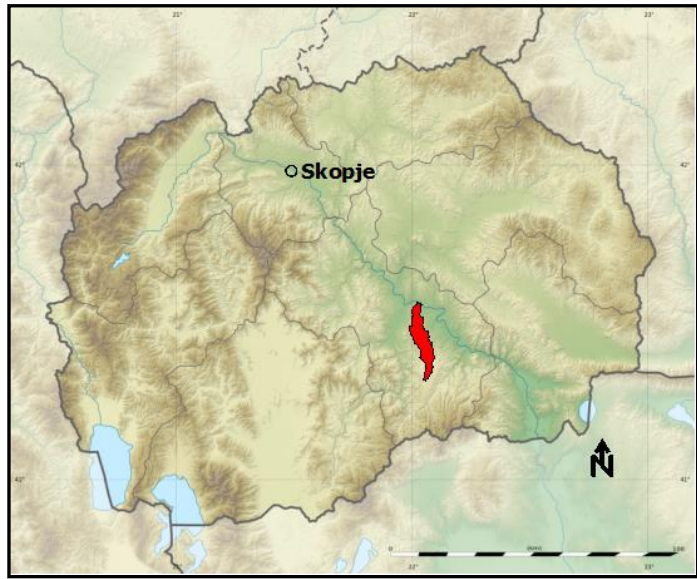

Figure 1. The catchment area of River Luda Mara in the Republic of Macedonia attention to small rivers in the Republic of Macedonia - which are not subject to any adequate monitoring - has been paid so far, or if it has, it has been made incidentally; on the other hand, they have great significance in water supply, agriculture and energy supply to the population in their catchment area [7].

\section{STUDY AREA}

The basin of the Luda Mara River is located in the Tikves Basin, covering parts of the south and central regions of the Republic of Macedonia. Spatially, the catchment area having an elongated shape in a meridian direction is located between $41^{\circ} 18^{\prime}-41^{\circ} 343^{\prime} \mathbf{N}$ and $21^{\circ} 58^{\prime}-22^{\circ} 06^{\prime} \mathbf{E}$. The area of the drainage basin of the Luda Mara River in its natural boundaries, measured by the watershed line is $140.5 \mathrm{~km}^{2}$, or $0.55 \%$ of the area of the Republic of Macedonia (Fig. 1). It is created through the merger of the Bunarska Reka, which originates at 900 meters above the sea level and the Sigjavica, whose spring is at 860 meters above the sea level. The confluence of the Luda Mara, is located at the elevation of 125 meters. The total 32,677 people populate seven rural settlements and one urban settlement, Kavadarci in the drainage basin area of the Luda Mara. The population density is 232.5 inhabitants $/ \mathrm{km}^{2}$ which is almost three times the national average of 79 inhabitants $/ \mathrm{km}^{2}$.

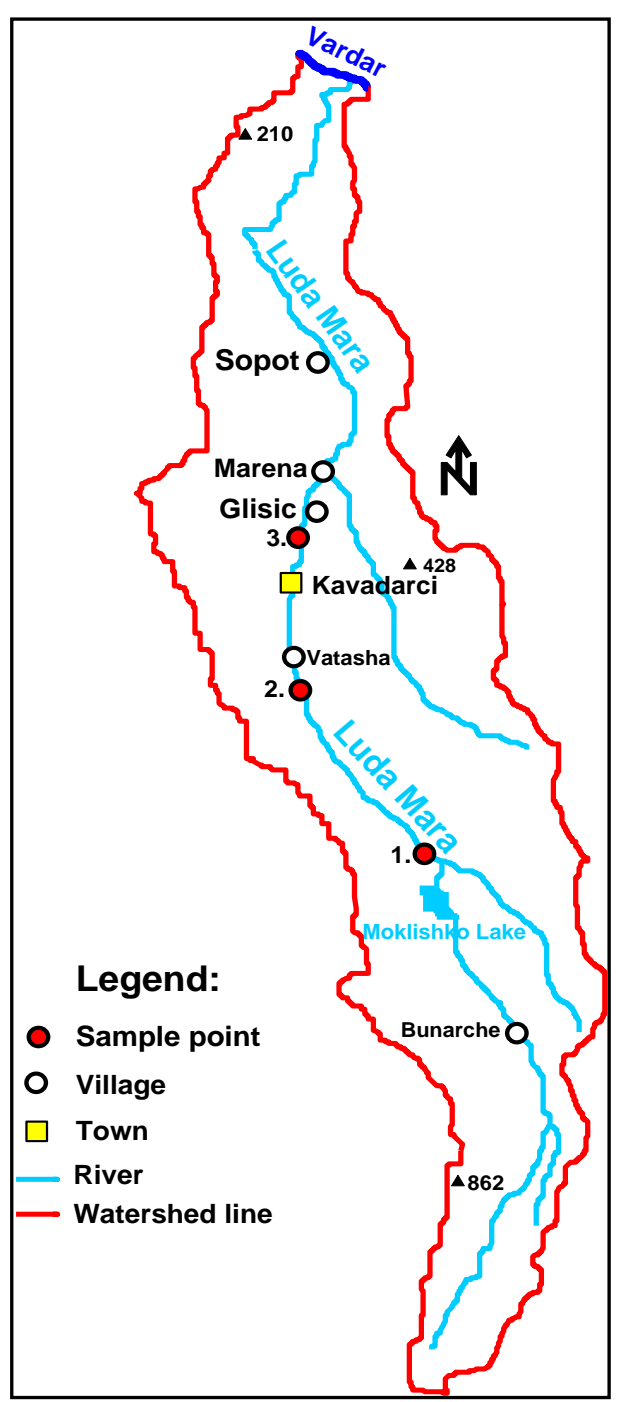

Figure 2. The drainage basin of River Luda Mara 


\section{METHODS AND DESIGN}

Accomplishing the main goals in the research activity directed towards an unbiased assessment of quality and pollution of the Luda Mara River water during 2010, necessitated a series of procedures and methods. Long-term terrain observation was necessary for purposeful selection of measurement points along the river course for sampling water and sediment. The selection of measurement points was made comprehensively, starting from objective clues that pointed indirectly or directly to some anomalies in quality of the river water. Thus, three points were selected. The first one in the upper, hillocky part of the Luda Mara course (Point 1, Fig. 2) was planned to be an indicator of water quality in an area where the human factor was excluded. The second measurement point (Point 2, Fig. 2) was in the middle part of the water course where the human factor was at minimum and increased gradually. The third measurement point (Point 3, Fig. 3) was located downstream the town of Kavadarci, with a purpose of assessing the anthropogenic influence of urban and rural population on water quality. Samples from the spring-summer and autumn-winter trials were delivered for analysis to two institutions: the Institute for Public Health and the Laboratory for Atomic Spectroscopy with the Institute of Chemistry at the Faculty of Natural Sciences and Mathematics in Skopje. Besides samples of water in the autumn-winter trial, samples of river sediments were taken with the purpose of coming to an idea of possible contamination of the river systems in the past. Concentration of heavy metals in the river sediment is expressed in $\mathrm{mg} / \mathrm{kg}$. Samples were taken in polyethylene containers precleaned with $\mathrm{HNO}_{3}(1+9)$, in line with ISO 5667-3. Measurements were made indirectly, with the assistance of a professional - lab operator, and the Perkin Elmer 3110 model, Flame Atomic Absorption Spectrophotometer (FAAS) measurement instrument was used. Results of laboratory analysis were subject in the further procedure to treatment with corresponding mathematical - statistic analysis. They are presented in form of tables and graphs with a purpose of getting insight in the annual regime of value of examined parameters as a criterion for quality of water in the river.

\section{RESULTS AND DISCUSSION}

Results of the basic physical and chemical analysis of water of the Luda Mara during 2010 at the measurement points: Mokliste (point 1, fig. 2), Vatasa (point 2, fig. 2) and Glisić (point 3, fig. 2) are given below (Table 1, Fig. 3).

Table 1. Mean values of the basic physical and chemical analysis of water in 2010 (in mg/l)

\begin{tabular}{|l|c|c|c|}
\hline \multirow{2}{*}{ Indicator $(\mathbf{m g} / \mathbf{l})$} & \multicolumn{3}{|c|}{ S A M P L E P O I N T S } \\
\cline { 2 - 4 } & Point 1. & Point 2. & Point 3. \\
\hline $\mathrm{pH}$ & 7.4 & 7.7 & 7 \\
\hline $\mathrm{COD}\left(\mathrm{KmnO}_{4}\right)$ & 9.05 & 5.9 & 35.6 \\
\hline Ammonia $\left(\mathrm{NH}_{3}\right)$ & 0.01 & 0.02 & 0.5 \\
\hline Nitrites $\left(\mathrm{NO}_{2}\right)$ & 0.032 & 0 & 0 \\
\hline Nitrates $\left(\mathrm{NO}_{3}\right)$ & 0 & 0 & 39.9 \\
\hline Chlorides & 4.2 & 7.6 & 25.6 \\
\hline Sulphates & 11.5 & 8.9 & $\mathrm{~d}=8.2$ \\
\hline Total hardness & $\mathrm{d}=5.7$ & $\mathrm{~d}=7.4$ & \\
\hline
\end{tabular}




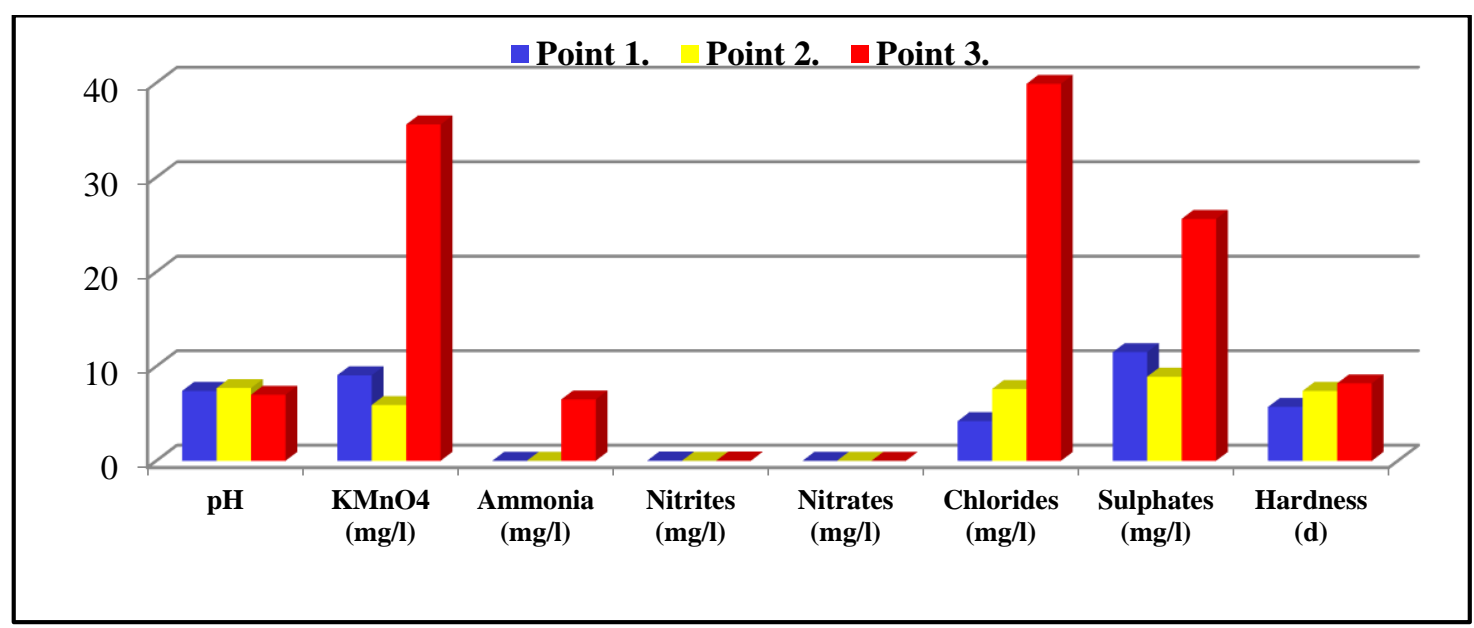

Figure 3. Mean values of the basic physical and chemical analysis of water in 2010 (in mg/l)

The indicator of acidity ( $\mathrm{pH}$ exponent) shows that water of the Luda Mara at all three measurement points shows average values of 7.0 (point 3) to 7.7 (point 3). This indicator shows that water in the river moves from weakly alkaline to neutral and corresponds to the I class according to quality, if one knows that it varies from $\mathrm{pH} 6.5-8.0$ [1]. Chemical consumption of oxygen $\left(\mathrm{KMnO}_{4}\right)$ at all three measurement points refers to increased organic load of the river. At the first and second measurement points, values correspond to quality of the III class, and at the measurement point near Glisic (point 3), downstream Kavadarci, the condition is significantly deteriorated and quality corresponds to the $\mathrm{V}$ class (Table 1, Fig. 3). Such a situation undoubtedly reflects the anthropogenic pressure on the water quality, which deteriorates on the section of the river downstream the city agglomeration. Annual movement of concentration of ammonia $\left(\mathrm{NH}_{3}\right)$ at the first and second measurement points on the Luda Mara (point 1; point 2) where the anthropogenic factor is minimal, moves within the boundaries for quality of the I-II classes. At the monitoring point downstream Kavadarci (point 3) the condition is disastrous. Here, over the year, concentration of ammonia is $6.5 \mathrm{mg} / \mathrm{l}$ and corresponds to quality of the V class (Table 1, Fig. 3). This undoubtedly reflects the human factor having in mind that ammonia is an indicator for faecal contamination of rivers [3]. One strongly toxic form of the nitrogen in the water is the nitrite ion $\left(\mathrm{NO}_{2}^{-}\right)$. Nitrite $\left(\mathrm{NO}_{2}{ }^{-}\right)$is a measure of a form of nitrogen that occurs as an intermediate in the nitrogen cycle [4]. It is an unstable form that is either rapidly oxidized to nitrate (nitrification) or reduced to nitrogen gas (denitrification). Thus, its concentration over the year in the Luda Mara water at the first and third measurement points (point 1 ; point 3 ) constantly exceeds the quality norms of the III-IV class (Table 1, Fig. 3). With the nitrite ion $\left(\mathrm{NO}_{3}{ }^{-}\right)$, no anomalous concentrations in the water were detected at all monitoring points. With the parameters: chlorides and sulphates and total hardness, increased concentrations downstream the river were observed, though they are not preferred for classification of water quality under the legal regulation of the Republic of Macedonia. Still, their downstream increase is reflection of increased pollution of the Luda Mara River, if one knows, for example, that the limit value for unpolluted water according to sulphates is $16.1 \mathrm{mg} / \mathrm{l}$ [10], the value of which is exceeded at Glisić (point 3) by $25.6 \mathrm{mg} / \mathrm{l}$ (Table 1, Fig. 3). 
Table 2. Average values of some metals in water in 2010 (in $\mu \mathrm{g} / \mathrm{l})$

\begin{tabular}{|c|c|c|c|}
\hline \multirow{2}{*}{ Indicator $(\boldsymbol{\mu g} / \mathbf{l})$} & \multicolumn{3}{|c|}{ S A M P L E P O I N T S } \\
\cline { 2 - 4 } $\mathbf{A l}$ & Point 1. & Point 2. & Point 3. \\
\hline $\mathbf{A s}$ & 152.1 & 174.4 & 45.1 \\
\hline $\mathbf{C u}$ & 11.3 & 10.2 & 2.7 \\
\hline $\mathbf{F e}$ & 1.1 & 4.9 & 59.0 \\
\hline $\mathbf{M n}$ & 17.2 & 135.4 & 58.5 \\
\hline $\mathbf{C d}$ & 3.1 & 3.8 & 3.0 \\
\hline $\mathbf{Z n}$ & 1.1 & 3.1 & 36.0 \\
\hline $\mathbf{N i}$ & 2.2 & 4.0 & 2.0 \\
\hline $\mathbf{P b}$ & 6.2 & 5.1 & 8.2 \\
\hline $\mathbf{C r}$ & 1.1 & 7.0 & 1.0 \\
\hline
\end{tabular}

Table 3. Average values of some metals in sediment in 2010 (in $\mathrm{mg} / \mathrm{kg}$ )

\begin{tabular}{|c|c|c|c|}
\hline \multirow{2}{*}{ Indicator (mg/kg) } & \multicolumn{3}{|c|}{ S A M P L E P O I N T S } \\
\cline { 2 - 4 } & Point 1. & Point 2. & Point 3. \\
\hline $\mathbf{A l}$ & 28162 & 29270 & 31571 \\
\hline $\mathbf{F e}$ & 10.3 & 14.6 & 37.6 \\
\hline $\mathbf{M n}$ & 17342 & 18591 & 20538 \\
\hline $\mathbf{Z n}$ & 321 & 340 & 386 \\
\hline $\mathbf{N i}$ & 24.3 & 43.3 & 109 \\
\hline $\mathbf{P b}$ & 26.1 & 28.0 & 62.7 \\
\hline $\mathbf{C r}$ & 8.5 & 9.6 & 28.7 \\
\hline
\end{tabular}

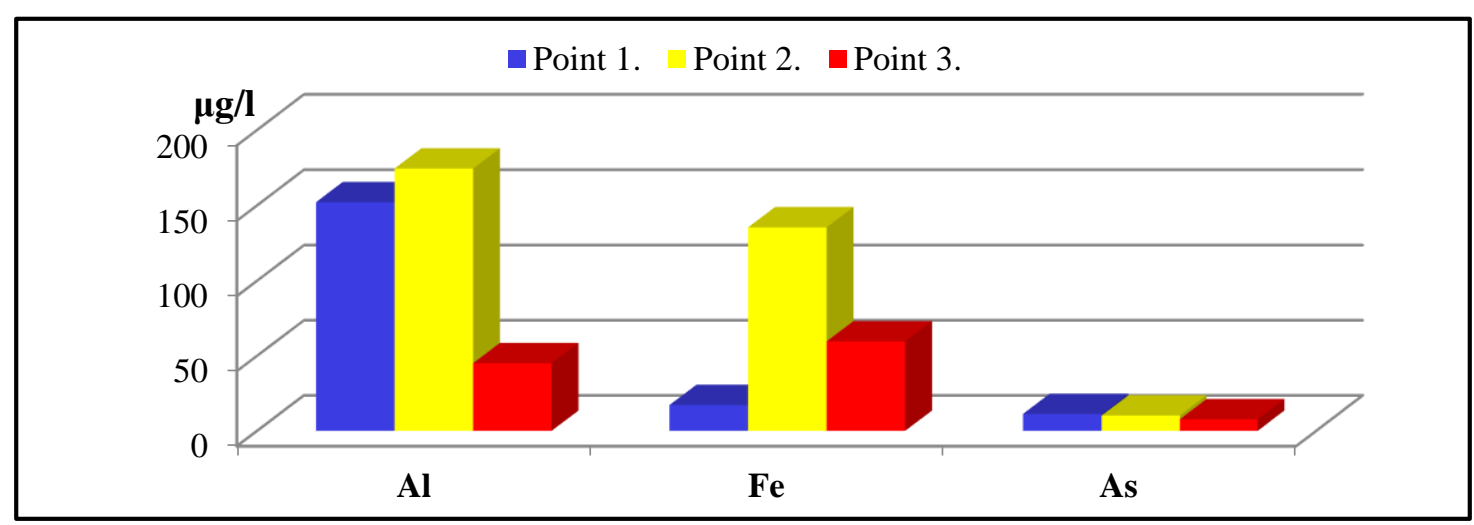

Figure 4. Average values of concentrations of: aluminum, iron and arsenic in the Luda Mara water (in $\mu \mathrm{g} / \mathrm{l}$ )

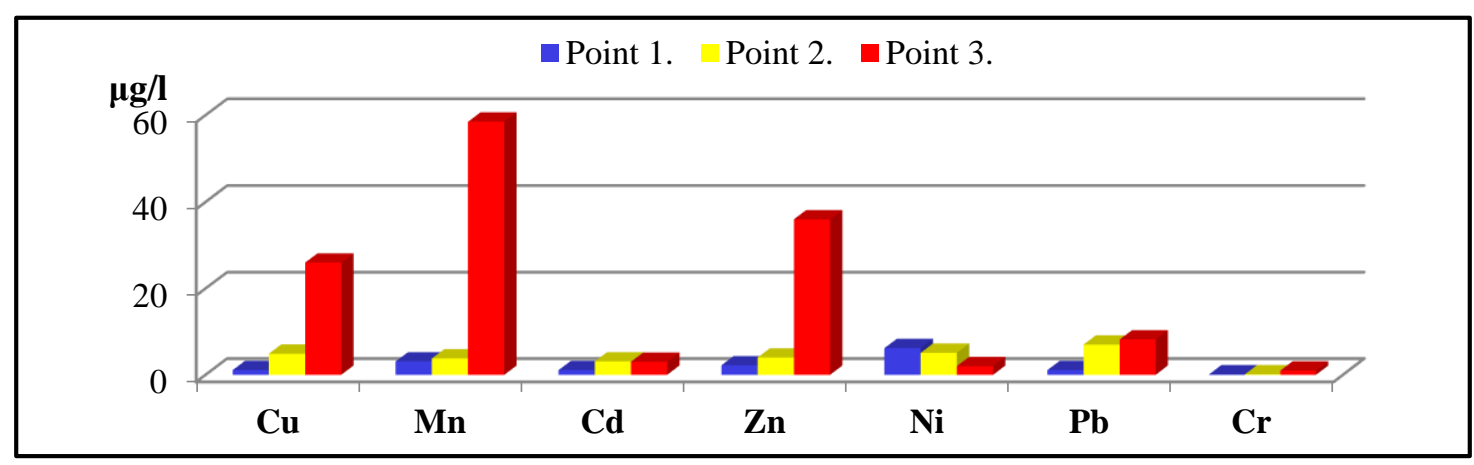

Figure 5. Average values of concentrations of some metals in the Luda Mara water (in $\mu \mathrm{g} / \mathrm{l}$ ) 


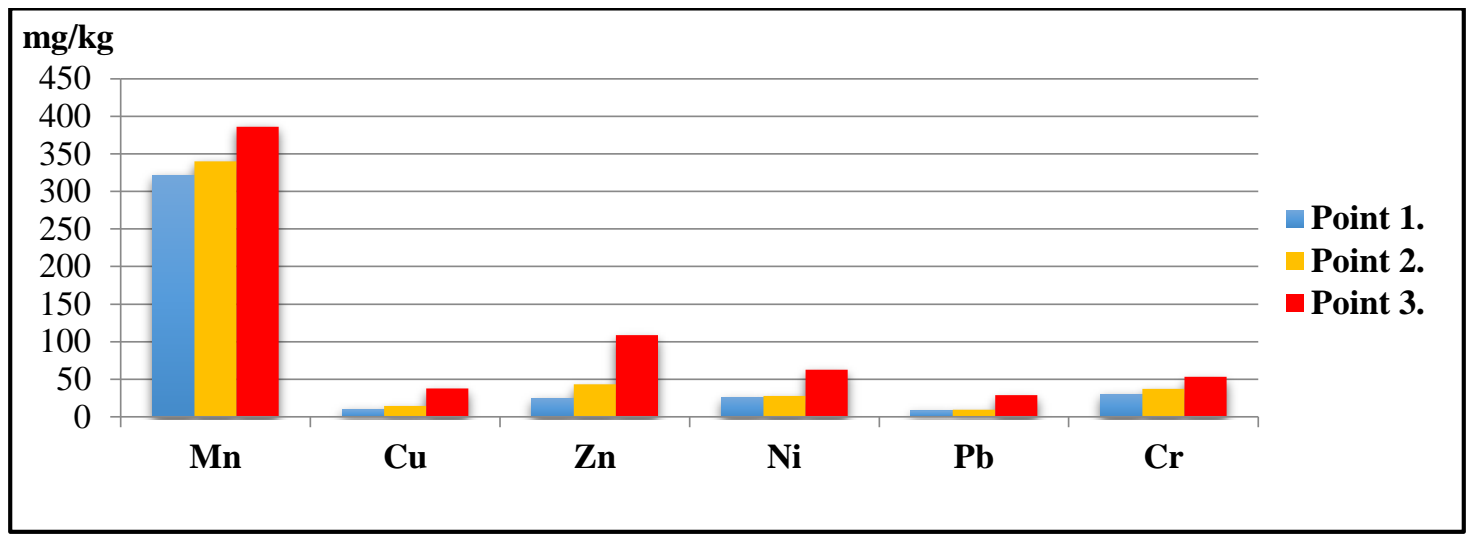

Figure 7. Average values of concentrations of some metals in the sediment of the Luda Mara River (in $\mathrm{mg} / \mathrm{kg}$ )

Analysis of samples from the Luda Mara water in relation to some heavy and toxic metals present in the water showed that critical concentrations were only observed in relation to cadmium, copper and manganese. Cadmium value over the year is constantly present at all three measurement points (points 1,2,3) and refers to concentrations for the III-IV class (Table 2, Fig. 5). Taking into account that its value downstream the river does not increase and the spring area of the Luda Mara is connected to the volcanic area of KožufVitačevo, a conclusion that its prevalence is of natural origin, of dissolved minerals from the geological substrate $[5,8]$ is undisputable. Actually, with almost all rivers whose springs are related to the said volcano area cadmium level is anomalously increased, without anthropogenic involvement [2]. With concentrations of manganese and copper, which are naturally represented at the first measurement points (point 1, point 2), enormous increase of concentrations in the water at the measurement point downstream the town of Kavadarci (point 3) is observable. Here, manganese represented with 58.5 $\mu \mathrm{g} / \mathrm{l}$ and copper with $26.0 \mu \mathrm{g} / \mathrm{l}$ correspond to quality of the III-IV class (Table 2, Fig. 5). Increased concentrations in water at the lower point of the river (point 3) downstream the town of Kavadarci are also observed in case of other four heavy metals such as: iron, zinc, lead, and chromium, although samples tested for these metals showed values for quality of the I-II class (Table 2, Fig. 4, 5). A tendency towards moderate or critical increase of concentrations of heavy metals in the water of the Luda Mara River (manganese, copper, iron, zinc, lead, and chromium), downstream the town of Kavadarci (point 3), is a sufficient sign of a need to emphasise the negative anthropogenic influence of the town of Kavadarci and surrounding villages, whose wastewater, is absorbed not purified by the examined river. Thus, concentration of heavy metals in the Luda Mara increases downstream the urban zone, which is a result of numerous industrial facilities whose outlets end in the Luda Mara, most frequently without any previous purification treatment (metal processing, tobacco, wood processing, textile, food processing and electrical industries). Values of analysis of concentration of some heavy metals in the sediment of the river, carried out in line with the Dutch standards [11], generally correspond with such a conclusion. With all tested metals, increase of concentrations at the lower point (point 3 ) is observable. Exceeding reference values for correctness of the soil is only visible with nickel and copper (Table 3, Fig. 7) which demonstrates in its own right their permanent deposits in retrospective, which has loaded the Luda Mara downstream the town of Kavadarci for a while; this is most likely the consequence of metal processing facilities located in the immediate proximity to the riverbed. The exceeded reference values of 
copper and nickel in the sediment of the Luda Mara (point 3) show that regardless of their low share in the water, they have been anomalously present in retrospective, and were sorbed on the sediments, as analyses show. The increasing tendency (below MAC) for other heavy metals in the sediment (Table 3, Fig. 6,7) at the measurement point near Glisić (point 3) most probably results from industrial as well as natural geogene activities, taking into account that natural, geogene enrichment of soil with some heavy metals has been proved in the Kavadarci surroundings [9].

\section{CONCLUSION}

Based on the conducted monitoring of quality of water of the Luda Mara River at three intendedly selected locations during 2010, where a few basic physical and chemical parameters and a few chemical-toxic metals were taken as a criterion, it can be decided that the lowest cumulative quality is typical in the lower course, near the village of Glisic (point 3), downstream the urban settlement of Kavadarci where the river is the recepient of urban and industrial wastewater, which are input untreated into its bed. Increased organic loading of the river with critically represented concentrations of chemical consumption of the oxygen $\left(\mathrm{KmnO}_{4}\right)$, ammonia (V class) and nitrites (III-IV class) is visible here. Concerning the group of tested heavy metals at the same point, unallowed concentration of manganese, copper and cadmium, which correspond to quality of the IIIIV class, was registered. Samples of sediment showed exceeded reference values for properness of soil in relation to copper and nickel, again at the lower measurement point (point 3). Except for three parameters (aluminium, iron, and arsenic), almost with all other parameters in water and sediment, regardless of their allowed or anomalous presence, their increasing concentrations are visible downstream the Luda Mara, i.e. a tendency of deterioration of the cumulative quality is visible. Exception to this tendency is the regime of cadmium in the water. Permanently present cadmium at all three measurement points show that its origin is natural. Other toxic metals are most critically represented in the Blasnica (arsenic, V class) and the Luda Mara (manganese, copper, cadmium, III-IV class). Sources of contaminating substances as factors for the defined level of pollution of the hillocky-mountainous rivers in the Tikves Basin are of natural and anthropogenic origin. Natural contamination is reflection of a high erosive power of torrential streams with reluctant waterflow, which intensively dissolve minerals from the soil. The mosaiclike geological composition and accelerated fluvial denudation processes are responsible for the washing out and enriching of the rivers with suspended and dissolved substances [8]. Naturally increased concentration (above MAC) of cadmium occurs in almost all rivers in Tikveš the spring section of which are located in mountains covered with young volcanism since the Pleistocene, and concentrations of nickel and chromium are registered in the sediment $[5,6]$. Anthropogenic sources of pollutants are the strongest agents for change of quality of water based on several criteria. Powerful factors in this group include urban, rural and industrial wastewater, which is drained in the Luda Mara untreated. Industry is involved through the capacities in the mining, food processing, metal processing, and construction material industries. Not any factory in the region has a collector system for disposal of wastewater, except for some enterprises which perform pre-treatment with settlers. The largest pressure is exerted by capacities in the metal processing industry of the town of Kavadarci, which load the Luda Mara with manganese, copper and cadmium downstream.

\section{REFERENCES}


[1] Addy K., Green L., Herron E. Ph and Alkality. 2004, Kingston, URI Watershed Watch, pp1-4

[2] Boev B., Jankovic S. Nickel and Nickeliferous-iron Deposits of the Vardar Zone (SE Europe) With Particular Reference to the Rzanovo - Studena Voda Ore-Bearing Series, Faculty of Mining and Geology, Stip, 1996.

[3] Harrison R. M. An Introduction to Pollution Science. 2006, Cambridge, Royal Society of Chemistry

[4] Ramani S., Bojkovska R., Pavlov K. Environmental Assessment of Water quality of the River Strumica During the last ten years with Overview on 2008. 2010, Ohrid, Balwoise

[5] K. Pavlov, The Influence of Natural and Antropogenal Factors on Water Pollution in Tikveš Basin (PhD thesis), Skopje, Faculty of Natural Sciences and Mathematics (in Macedonian), 2011.

[6] Pavlov K., Bačeva K., Stafilov T., Vasileski D., Toševska S. Assessment of Toxic Metal Pollution in Some Rivers in the Tikveš Basin, Republic of Macedonia. 2012, International Journal of Environmental Protection Dec. 2012, Vol. 2 Iss. 12, PP. 9-16 [7] Pavlov K., Milenkovski A., Pavlovski G. Geographical Factors in Function of Viniculture and Vine Tourism Development in the Tikvesh Basin. 2014, Skopje, UTMS Journal of Economics 5 (1): 89-102

[8] Pavlov K., Pavlovski G., Radevski I. HEAVY METAL CONTAMINATION OF SOME RIVERS IN THE HILLY AND MOUNTAINOUS AREAS OF TIKVES̆. 2013, Skopje 2014 Preceedings of Scientific Congress: Problems and perspectives of hilly and mountainous areas in Republic of Macedonia (in Macedonian with English summary)

[9] Stafilov T., Šajn R., Boev B., Cvetković J., Mukaetov D. and M. Andreevski, Geochemical Atlas of Kavadarci and the En-virons, Skopje, Faculty of Natural Sciences and Mathematics, 2008.

[9] Stafilov T., Šajn R., Boev B., Cvetković J., Mukaetov D., Andreevski M. and S. Lepitkova, Distribution of Some Elements in Surface Soil Over the Kavadarci Region, Republic of Macedonia, Environmental Earth Sciences, 61(7), 1515-1530, 2010.

[10] Walther J.V. Essential of Geochemistry. 2005, Sudbury, Jones and Bartlett Publishers

[11] The new Dutchlist, [Online]. Available: http://www.contaminatedland.co.uk/stdguid/dutch-1.htm. 